ARTIGOS

\title{
As memórias do imemorável por uma educação contra o esquecimento e a barbárie ${ }^{1}$
}

\section{Memories of the immemorial for an education against oblivion and barbarism}

\section{Memorias de lo inmemorial para una educación contra el olvido y la barbarie}

\begin{abstract}
(i) Universidade Federal Fluminense - UFF, Niterói, RJ, Brasil. https://orcid.org/0000-0002-13015709, celo.sferreira@gmail.com.

(ii) Universidade Federal de Rondonópolis - UFR, MT, Brasil. https://orcid.org/0000-0002-8730-3025, ramidan@terra.com.br.
\end{abstract}

\begin{abstract}
Resumo:
Este artigo tem como foco as memórias como aparecimento social e resistência ao apagamento e ao sufocamento do luto compulsórios. As análises voltam-se para narrativas que, reservadas as suas diferenças e singularidades, trazem vidas e histórias cujas barbáries, ao aparecerem na vida política do presente, emergem como modos de escavar a história e a vida em sua perspectiva totalitária e desenvolvimentista. Essas narrativas são: memórias da ditadura e do exílio, que resistem ao apagamento social, trazendo à cena pública a experiência do luto; e memórias de infâncias dissidentes à heteronormatividade e marcadas por violências alinhadas a essa norma, cuja escritura faz aparecer socialmente o que não pode existir.

Palavras-chave: memórias, totalitarismo, violências de gênero
\end{abstract}

\footnotetext{
${ }^{1}$ Normalização, preparação e revisão textual: Douglas Mattos (Tikinet) - revisao@tikinet.com.br
} 


\begin{abstract}
:
This paper focuses on memories as social appearance and resistance to the compulsory erasure and suffocation of mourning. The analyzes refer to narratives that, reserved for their differences and singularities, bring lives and stories whose barbarities, appearing in the political life of the present, emerge as ways of excavating history and life in their totalitarian and developmental perspective. These narratives are: memories of dictatorship and exile, which resist to social erasure, bringing to the public scene the experience of mourning; and memories of childhoods dissident to beteronormativity and marked by violence aligned with this norm, whose writing makes socially appear what cannot exist.
\end{abstract}

Keywords: memories, totalitarianism, gender violence

\title{
Resumen:
}

Este articulo se centra en memorias como aparecimiento social y resistencia a la eliminación obligatoria y a la supresión del dolor. Los análisis recurren a narrativas que, reservadas por sus diferencias y singularidades, traen vidas e historias cuya barbarie, al aparecer en la vida politica actual, emergen como formas de excavar la historia y la vida en su perspectiva totalitaria y desarrollista. Estas narrativas son: memorias de la dictadura y el exilio, que resisten al apagamiento social, trayendo a la escena pública la experiencia del duelo; y memorias de infancias disidentes de la heteronormatividad y marcadas por violencias alineadas con esta norma, cuya escritura hace socialmente visible lo que no puede existir.

Palabras clave: memorias, totalitarismo, violencia de género

\section{Introdução}

Em tempos de produção do silêncio, de palavras amordaçadas, de memórias da dor e do horror apagadas, o aparecimento como ação política que resiste ao esquecimento faz-se necessário e urgente.

No Brasil desta última década, diversas investidas na vida política têm se dedicado à produção de temas "malditos", alvos de censuras e profanações, sobretudo no contexto da educação. Entre esses temas, a palavra "gênero" tem assumido protagonismo como a expressão de uma suposta ideologia que destrói tanto a família, em sua estrutura nuclear e tradicional, quanto a inocência da infância, noção também produzida secularmente para dar sustentação a subjetividades e relações sociais requisitadas pelo modus operandi da sociedade ocidental. 


\section{pro.posıções}

$e$-ISSN 1980-6248

http://dx.doi.org/10.1590/1980-6248-2019-0093

Setores da sociedade civil e governantes das esferas municipal, estadual e federal, inspirados em princípios moralistas e fundamentalistas religiosos, organizam-se em torno de pautas proibitivas e criminalizadoras do debate e da produção de conhecimentos sobre vidas que não se alinham a uma existência consagrada como a ideal e, portanto, a única passível de chancela no mundo. A matriz biológica e binária, que demarca o masculino e o feminino alicerçados na heteronormatividade como fundamento de uma "natureza humana" e uma verdade da vida, é o que requer a proteção do Estado. Vidas vigiadas, violentadas e desqualificadas como vidas, porque não se enquadram nas normas de gênero que se inscrevem como modos de existir legítimos e implacáveis, são as que precisam desaparecer, seja pelo silenciamento dos discursos na produção de não ditos, seja pela violência que opera para a sua destruição e para o extermínio de corpos sem deixar rastros, sem que isso seja assumido como um crime.

Nesse cenário de mordaças está também o apagamento de memórias de tragédias irreparáveis que marcam, de modo sangrento, a vida política em regimes ditatoriais cívicomilitares, instaurados na América Latina, na história recente. Discursos de consagração a esses regimes têm sido reiterados por governantes, políticos e cidadãos comuns nos últimos tempos no Brasil, como palavras de ordem que impõem ao presente o esquecimento dos mortos do passado e a proibição de seu luto, em favor do desenvolvimento e do progresso do Estadonação como promessa do futuro.

Imersos neste contexto de discursos sufocados, de vidas e corpos violados e do trágico relegado ao esquecimento, trazemos as memórias como modos de aparecer socialmente e resistir ao apagamento e ao impedimento do luto. Colocamo-nos diante da tarefa de, no campo da educação, manter viva a produção de narrativas que se responsabilizem por convocar as vozes, as experiências e as histórias condenadas pela narrativa épica do progresso a permanecer presas aos seus escombros. "Esburacar" - nos termos de Peter Pál Pelbart (2011) - a história e a vida em sua retórica totalitária e desenvolvimentista é o que aqui se pretende a partir da dialogia entre as memórias da ditadura e do exílio, de vidas aviltadas pelas barbáries impingidas por um Estado totalitário, e os fragmentos de memórias de infâncias, marcadas por experiências e corpos de crianças dissidentes à heteronormatividade, que são violados por não corresponderem a essa norma. Violências e violações que, no cotidiano da educação, se alimentam e são reiteradas, se não forem quebrados os elos que mantêm o funcionamento de sua engrenagem. Entendemos que a produção de memórias que vão na contramão das normas violadoras de 


\section{pro.posıções}

$e$-ISSN 1980-6248

http://dx.doi.org/10.1590/1980-6248-2019-0093

corpos e vidas possa quebrar esses elos ao abrir-se para o aparecimento de outras histórias possíveis.

Com os aportes principais das análises de Walter Benjamin, Judith Butler e Giorgio Agamben, essas memórias são assumidas como escrituras políticas que fazem aparecer socialmente o que não pode existir e resistem ao apagamento social como passado remoto, trazendo à cena pública a experiência do luto. Memórias que, seja pela violência praticada pelo Estado totalitário, seja pela violência de gênero, trazem vidas que, sob o crivo da narrativa do progresso e das normas de gênero, não podem existir, sobre as quais operam o esquecimento e o apagamento. Vidas nuas, para as quais a destruição ou a morte já não mais se configuram como crime (Agamben, 2002). Debruçamo-nos sobre essas memórias, ainda que produzidas em contextos e atravessadas por marcas de violência distintas - de um lado, as memórias do Estado de exceção e, de outro, as memórias de infâncias dissonantes às normas de gênero e sexualidade -, como disparadoras para reflexões sobre a educação como crítica à produção do esquecimento, seja pela via do amordaçamento do debate das violências, seja pela via da maldição e proibição de temas como parte de seu cotidiano.

O apagamento de vidas e memórias coloca-se como temática de dois livros de escritores latino-americanos contemporâneos, que são ressaltados na discussão que propomos no presente artigo. Roberto Bolaño (2009) e Julián Fuks (2015), com 17 anos de distância cronológica, propõem exercícios estéticos em seus respectivos livros $A$ muleto e $A$ resistência, que convergem na presente leitura. Bolaño, escritor chileno precocemente falecido em 2003, publica Amuleto em 1999, forjando um lugar enunciativo para uma narradora, Auxílio Lacouture, que se destaca como sobrevivente de um ataque de militares à Universidade Autônoma do México em 1968 ao esconder-se no banheiro feminino de uma das faculdades. Fuks, jovem escritor brasileiro de pais argentinos, escreve o romance $A$ resistência, em 2015, mesclando aspectos de sua biografia com elementos ficcionais de distintas naturezas e tematizando a fuga de cidadãos argentinos da ditadura sangrenta implantada naquele país, nos anos de 1970, para o Brasil, ao mesmo tempo em que formula uma personagem que sustém boa parte da narrativa, um irmão adotado pelos pais antes do nascimento do narrador e de sua irmã. Tornar possível a elaboração da figura do irmão coaduna-se com o desdobramento do luto pelo exílio. Os dois livros - salvaguardando as especificidades das obras - podem ser aproximados na problematização ética dos mecanismos de esquecimento compulsório a que somos submetidos sob a égide do terror do Estado, dialogando fortemente com os instrumentos de coerção impingidos a existências que são 


\section{pro.posıções}

$e$-ISSN 1980-6248

http://dx.doi.org/10.1590/1980-6248-2019-0093

dissidentes em relação às políticas de gênero e de sexualidade operatórias em sociedades como a brasileira.

Nessa costura com as dissidências de gênero, entram na dialogia deste texto fragmentos de memórias de infâncias que advêm da coletânea Mariconcitos: feminidades de niños, placeres de infancia, organizada pelos argentinos Juan Manuel Burgos e Emmanuel Theumer (2017), a qual reúne 75 narrativas de pessoas de países latino-americanos diversos, com destaque para a Argentina, e sendo apenas uma de Portugal. A coletânea está sob a forma de livro digital e é produzida a partir de um projeto autogestado ${ }^{2}$, com o propósito de compilar narrativas dissidentes de infâncias que interrogam masculinidades normativas postas e impostas por uma perspectiva teleológica da vida.

Voltamo-nos aos livros de Bolaño, de Fuks e Mariconcitos, no esforço de leitura de suas contribuições políticas e éticas para a interpretação de estratégias de elaboração de memórias como resistência ao apagamento do passado, sem liquidar o estatuto estético das composições, ou melhor, incluindo na interpretação o reconhecimento da estética em curso na escrita dos livros, peças fundamentais para a compreensão da lembrança como contraposição à absolutização e ao apagamento do passado.

\section{História, memória e vida: os escombros da narrativa do esquecimento}

Não podemos perder de vista que nossa posição em relação à literatura se nutre da perspectiva aberta pelos estudos de Walter Benjamin (2011) em relação ao tempo que o texto literário transcorre para alcançar seus leitores. Embora os textos não se destinem a um leitor ou leitora idealizados, eles se encontram tingidos pelo tempo que tornou possível que os interpretemos. As marcas indeléveis dos textos dizem respeito ao processo de escritura, às práticas de tradução e à própria recepção dos livros. Roberto Bolaño (2009) não se cansa de indicar a tensão entre a literatura e a vida, multiplicando as referencialidades que se apresentam para a composição de personagens, podendo nos servir como expressão de prática literária

\footnotetext{
2 O projeto teve início em abril de 2016, a partir de convocatórias on-line, disponíveis no site http://proyectomariconcitos.blogspot.com, para que pessoas escrevessem e postassem uma fotografia e suas narrativas dissidentes de infância.
} 
indicativa de uma posição política em relação ao que transcorre. Caracterizando Auxílio Lacouture, a narradora do romance Amuleto, como a mãe dos poetas mexicanos dos anos 1970 - jovens que não tiveram tempo de ser reconhecidos, uma geração "desaparecida" por intermédio de práticas de perseguição política e de extermínio levadas a cabo de diferentes formas na América Latina -, o escritor chileno propõe múltiplas imagens do exercício de composição de um lugar enunciativo precário, mas resistente ao apagamento, costurando distintas regiões de contato entre a atividade reminiscente da narradora e o próprio exercício literário. No início, se apresenta o “eu”, figura que será permanentemente diluída e ameaçada pelas recordações e profecias que se apresentarão, relacionadas, em grande medida, ao sentido do exercício literário, a conexão que se pode estabelecer entre a vida e a literatura, que ingratamente parecem se dissociar quando se busca uma referência absoluta antes que se comece a escrever ou lembrar. Falar sobre a perda de uma geração não é um exercício simples, principalmente quando se escreve também a partir da condição de exilado, como o foi para o próprio Roberto Bolaño.

Esta será uma história de terror. Será uma história policial ... Mas não parecerá. Não parecerá porque sou eu que conto. Sou eu que falo e por isso não parecerá. Mas no fundo é a história de um crime atroz.

Sou a amiga de todos os mexicanos. Poderia dizer: sou a mãe da poesia mexicana, mas acho melhor não dizer. Conheço todos os poetas e todos os poetas me conhecem. De modo que poderia dizê-lo ...

O que, sim, posso dizer é meu nome.

Eu me chamo Auxílio Lacouture e sou uruguaia, de Montevidéu, mas quando os vapores me sobem à cabeça, os vapores da saudade, digo que sou charrua, o que vem a ser a mesma coisa, apesar de não ser, e o que confunde os mexicanos, e portanto os latino-americanos. (Bolaño, 2009, pp. 9-10)

Desde o início do romance, Lacouture exige certo procedimento sobre aquilo que narrará, já que mesmo diante da tarefa de falar sobre a perda e sobre o risco, o estatuto de quem narra pode servir como modelador do que advirá. Lacouture procede a uma modificação do tempo, garantindo as primeiras pistas importantes para defendermos que no texto literário se desenrola uma política de memória. "Estiquemos o tempo como a pele de uma mulher desacordada na sala de operações de um cirurgião plástico” (Bolaño, 2009, p. 10). Ao esticar o tempo no exercício de lembrar e de prever, a narradora posiciona-se como alguém que trabalha 
na casa de jovens poetas, por volta do ano de 1965, no México. A mesma mulher ainda trabalhará, de forma episódica, em diferentes lugares. Na casa de dois jovens poetas, Lacouture angustia-se com a poeira que cobre os livros, mesmo que os poetas lhe digam que a literatura sempre se entendeu com a poeira. A narradora gostaria de limpar, mas é o seu próprio argumento que permitirá uma distensão do tempo, invocando o que já havia lido e evocando o que ainda não pôde ler. Bolaño (2009) assim compõe esse momento:

e então tudo ficava coberto pela poeirada, os livros que eu havia lido e os livros que pensava ler, e aí já não havia nada que fazer, por mais que usasse a vassoura e o pano de pó a poeira nunca iria embora, porque essa poeira era parte consubstancial dos livros, e ali, à sua maneira, eles viviam ou remedavam algo parecido com a vida. (p. 11)

Ao encontrar uma tarefa temporária na casa dos dois poetas, a personagem acaba indicando aspectos importantes da conjunção da literatura com o tempo e, fundamentalmente, com a vida. A narradora decidirá, a partir da lembrança, do esquecimento e do delírio, que os rastros das coisas e dos sentimentos não sucumbirão ao tempo. A poeira acumulada sobre os livros - principalmente sobre aqueles livros que a personagem ainda não havia lido e os que não haviam sido escritos ainda - chama atenção de uma das personagens lembradas, o jovem Arturo Belano, que parece se dedicar a olhar tristemente para um canto da sala de sua própria casa. $\mathrm{O}$ que haveria escondido sob aquela poeira? Lacouture imagina que aquele canto era como uma boca do inferno. A personagem não se esquiva de lembrar, remetida a datas recuadas ou colocadas muito à frente do momento em que vive seu infortúnio e salvação, alguns dias presa num banheiro. Lacouture talvez evoque uma efetiva sobrevivente da invasão militar à Universidade Autônoma do México, e a tônica da escrita de Bolaño, no caso do romance específico, parece ser a proliferação de lugares enunciativos, ou melhor, a defesa da heterogeneidade de subsídios para que se forje um lugar enunciativo. A sobrevivente, que se autodesigna “a mãe caminhante” (Bolaño, 2009, p. 58), vê-se reduzida apenas a si mesma, quando consegue se manter no banheiro feminino da Faculdade de Letras, e volta-se a um escrutínio febril do passado e à imaginação sobre os anos vindouros, tanto em relação à literatura quanto à situação política no México e no restante da América Latina. A que a personagem se fia? A sua própria memória, fragmentada, no entanto, em temporalidades difusas. A indecidibilidade da personagem entre o que houve de fato e o que não se sabe se ocorreu efetivamente não parece muito distante do próprio sentido da atividade reminiscente que não se apodera do passado como algo em si mesmo, mas que resiste ao seu apagamento. Citando o 


\section{pro.posıções}

$e$-ISSN 1980-6248

http://dx.doi.org/10.1590/1980-6248-2019-0093

massacre de estudantes em 1968 por forças opressoras do Estado mexicano em Tlatelolco, às vésperas das Olimpíadas que se realizaram no país, Bolaño (2009), por intermédio de Lacouture, encontra um antídoto estético e político ao esquecimento, resguardando o combustível com que a memória encontrará refúgio em direção ao passado e ao futuro, como marcas deixadas para distintos leitores. O ano de 1968 é de muita importância por diferentes motivos, entre os quais, a capacidade de mobilização de contingentes oprimidos e a resposta oficial dos governantes em termos do estabelecimento de práticas terroristas de condução da vida social. Quanto a isso, Lacouture pronuncia-se no misto de afetos que se relacionam em sua lembrança restauradora e criativa:

Ai, lembrar disso me faz rir. Que vontade de chorar! Estou chorando? Vi tudo e, ao mesmo tempo, não vi nada. Entendem o que quero dizer? Sou a mãe de todos os poetas e não permiti (ou o destino não permitiu) que o pesadelo me desmoronasse. As lágrimas agora escorrem por minhas faces estragadas. Eu estava na faculdade naquele 18 de setembro em que o exército violou a autonomia e entrou no campus para prender ou matar todo o mundo. Não. $\mathrm{Na}$ Universidade não houve muitos mortos. Foi em Tlatelolco. Esse nome há de ficar em nossa memória para sempre! (Bolaño, 2009, p. 23)

Aparentando-se a um testemunho, a personagem dirige-se a um destinatário, em um complexo jogo de espelhos em que ousamos perceber a incitação para potenciais leitores, aqueles que poderão libertar, momentaneamente, o livro da poeira assentada sobre si. A dispersão e a inconclusividade da memória não sustentam o revisionismo conservador sobre o passado recente - como se tornou corriqueiro no Brasil contemporâneo -, mas justificam a elaboração de materiais e de exercícios que desdobrem aquilo que foi negado ou compulsoriamente esquecido. Trata-se de restos que não foram reconhecidos e vidas que foram interrompidas. A interpelação do tempo espesso, em oposição ao tempo homogêneo e vazio do continuísmo histórico, como apontava Benjamin (1985), viabiliza uma atividade reminiscente que sobrevive à linearidade da barbárie. Ainda em Bolaño (2009), encontramos uma importante explanação sobre a espessura do tempo:

Acho, permitam-me este inciso, que a vida está repleta de coisas enigmáticas, pequenos acontecimentos que só estão esperando o contato epidérmico, nosso olhar, para se desencadearem numa série de fatos causais que, depois, vistos através do prisma do tempo, não podem deixar de produzir em nós assombro e espanto. (p. 23)

O trabalho obstinado sobre o que emerge na lembrança não se perde da precariedade do lugar em que a narradora do romance se encontra. A luz que atravessa as camadas de tempo 


\section{pro.posıções}

$e$-ISSN 1980-6248

http://dx.doi.org/10.1590/1980-6248-2019-0093

e trazem aspectos do que foi vivido alcança, muitas vezes, o desenho dos azulejos do banheiro em que Lacouture se escondeu. Essa mesma luz - esse mesmo lume - viabiliza que um esforço seja feito em relação ao que foi perdido, destinando-lhe certo lugar no futuro que, paradoxalmente, é o agora do texto literário. A personagem defronta-se com o risco do esquecimento, tema múltiplas vezes evocado no romance. Esquecer algo, muitas vezes, parece com esquecer tudo. Quanto mais se esquece, mais se avoluma a quantidade de mortos irreconhecíveis sob os pés de homens e mulheres dos anos e séculos vindouros.

O exercício literário pode se configurar como uma parada em relação ao esquecimento forçado. O livro de Bolaño parece restaurar um dos sentidos etimológicos da palavra "livro", quando se recuperam suas raízes indo-europeias, relacionando-se com a atividade de descascar. A personagem forjada por Bolaño descasca aquilo que foi esquecido, permitindo que ainda se possa fazer uso do poder germinativo das sementes do que é compreendido historicamente. Ler esse livro também revela uma parte do sentido da própria época em que nos encontramos. Lacouture é uma "testemunha do tempo seco" (Bolaño, 2009, p. 75) e depara-se com as distintas dificuldades de manter-se sóbria enquanto, fora do banheiro, estudantes e trabalhadores são perseguidos politicamente. No lugar intersticial da sobrevivente, a personagem exprime parte dos esforços de Bolaño em produzir literatura sobre uma geração desaparecida. A personagemnarradora do livro em análise depara-se, também, com sua dificuldade em esquecer, o que dizem ser um problema, mas há momentos importantes do romance em que percebemos uma transmutação da fragilidade de quem está trancada em um banheiro - sem saber se sobreviverá - na força de uma pessoa que recorda. Frisemos esta transmutação: tornar-se a recordação, esforçar-se por garantir um pouso àquilo que se recorda, sem o risco de objetificar ou neutralizar a força política do que é recordado. Exatamente nesse momento, Lacouture inventa um modo de resistir. Podemos nos apropriar do sentido de resistência no romance de Bolaño como um antídoto para o apagamento. São as recordações de Lacouture, aquela que fala sempre colocando a mão direita sobre a boca para disfarçar os dentes que foram perdidos, que constituem a sua resistência. A personagem já havia experimentado a sua própria proximidade com os beatniks, na tentativa de tornar sua própria vida uma arte (Bolaño, 2009). Agora, no interior do exíguo e insólito banheiro da Faculdade de Letras, ela põe-se a recordar e profetizar, impulsionada pela mixagem em curso no tempo. Diante da fome e da solidão, a personagem inaugura uma atitude: “decidi resistir” (Bolaño, 2009, p. 123). 


\section{pro.posıções}

$e$-ISSN 1980-6248

http://dx.doi.org/10.1590/1980-6248-2019-0093

A resistência de Lacouture faz um tributo aos jovens desaparecidos da América Latina nos anos de 1960 e 1970, estabelecendo encontros imaginários que são curativos, como o que se dá entre a personagem e a pintora Remédios Varo, morta em 1963 na Cidade do México. Varo, no delírio curativo de Lacouture, indica a importância de que Auxílio sobreviva. Recordar será a sua tarefa. Não parece arbitrário que seja uma artista com forte proximidade com o surrealismo que apareça para conversar com a personagem, uma vez que, de acordo com o movimento estético, as forças do sonho e da embriaguez precisam ser mobilizadas para a relação com a vida ordinária. Mas, de acordo com Benjamin (1985), em sua apreensão do movimento surrealista, o que mais se podia destacar politicamente era a elaboração de uma zona intermediária entre o sonho e a vigília, que se trata do próprio despertar. Em diversos momentos do romance, a personagem exorta a si mesma a despertar, até que, finalmente, a vida possa prosseguir. Diante da pergunta essencial, "O que fazer?”, a personagem decide resistir, lembrar, despertar. A heterogeneidade do tempo em curso no romance de Bolaño (2009) viabiliza que a zona intermediária do despertar lance algumas luzes sobre o conteúdo de sonhos e a sobriedade da vigília. Os momentos do despertar são remetidos, de forma intermitente, ao espaço do banheiro em que a personagem se encontra, mesmo que, em algumas páginas, estejam sendo narradas situações vividas depois que a personagem conseguiu sair do banheiro. Esta multiplicidade do tempo pode ser apropriada na interpretação atual. A possibilidade de fazer literatura implica uma tomada de posição em relação ao presente. A tomada de posição encontra-se crivada, também, no romance de Bolaño, dos atributos risíveis e marginais da narradora.

Que importância os textos literários podem ter para o enfrentamento do silenciamento compulsório em curso numa ditadura, em uma prática revisionista sobre o passado, quando se conspurca a condição dos perseguidos que anseiam por restituição e reconhecimento do seu sofrimento? Assumimos que o estabelecimento de leituras múltiplas sobre o texto literário permite a ampliação do seu sentido, como parece sugerir Ricardo Piglia (2017) ao se dedicar a defender o lugar do leitor como aquele que recolhe um rastro do que não foi devidamente reconhecido, nem mesmo desdobrado. Citando leitores contumazes, Piglia faz uma importante afirmação em um dos seus ensaios: "há alguma coisa que deve ser preservada, alguma coisa que a leitura acumulou como experiência social. Não se trataria de exibição de cultura, mas, ao contrário, de cultura como resto, como ruína, como exemplo extremo do desprovimento" (pp. 100-101). 


\section{pro.posıções}

$e$-ISSN 1980-6248

http://dx.doi.org/10.1590/1980-6248-2019-0093

A leitura, para o ensaísta, configura-se como imagem intermediária entre o silêncio do livro e a passagem para a ação em um contexto de desolação. Livros podem interceptar leitores em situações extremas, a possibilidade de interpretar e estender o alcance do que foi lido são atitudes estéticas e políticas, a um só tempo. Defendemos que a multirreferencialidade em jogo no exercício literário de Bolaño (2009) viabiliza que alcancemos o resto de uma época, interrompendo o continuísmo histórico. Ao nos considerarmos como provisórios destinatários do que lemos, podemos nos voltar ao nosso próprio tempo. O próprio Bolaño evoca em seu romance o problema ético em torno do que se pode fazer com o que foi escrito. Auxílio Lacouture, quase ao final do romance, come um pequeno pedaço de papel higiênico e deparase com fragmentos de coisas que havia escrito sobre o tempo que já havia passado no banheiro. Joga tudo na latrina e dá a descarga. $\mathrm{O}$ barulho pode lhe denunciar na imensidão de silêncio em que a Universidade Autônoma do México se encontra.

Pensei: apesar de toda a minha astúcia e de todos os meus sacrifícios, estou perdida. Pensei: que ato poético destruir meus escritos. Pensei: melhor teria sido comê-los, agora estou perdida. Pensei: a vaidade da escrita, a vaidade da destruição. Pensei: porque escrevi, resisti. Pensei: porque destruí o escrito vão me descobrir, vão me pegar, vão me violentar, vão me matar. Pensei: ambos os fatos estão relacionados, escrever e destruir, se esconder e ser descoberta. Depois me sentei no trono e fechei os olhos. Depois adormeci. Depois acordei. (Bolaño, 2009, p. 125)

Aguentar e ser firme têm, no romance do escritor chileno, conexão com a atividade de escrever. A literatura pode acolher um ato de resistência, bem como lembrar e interromper o esquecimento a que parecemos estar fadados na América Latina. Escrever e destruir também estão em conexão, o que, transversalmente, aproxima o exercício de Bolaño daquele instituído por Julián Fuks (2015) no romance $A$ resistência. No caso de Fuks, há uma destinação da narrativa sobre a elaboração da figura do irmão adotivo ao próprio ato de escrever. Tematizando a ditadura na Argentina, a condição de exilados dos pais do narrador - condição herdada pelo narrador, como expressão trágica e política da distância que se assume em relação à cidade de Buenos Aires - complexifica-se com o sentido terapêutico que o livro parece assumir para a pessoa Julián Fuks e os seus próprios pais.

O livro de Fuks ganhou o Prêmio Jabuti em 2016, com o qual o autor conquistou uma considerável popularidade. Diante do sucesso do livro, o autor é convidado a falar sobre os efeitos do que havia escrito sobre a sua própria vida. Em entrevista a Paula Pires da Silva, na revista Cult, o escritor afirma que há uma ambiguidade no ato de escrever, em que, ao mesmo 
tempo, nos aproximamos de pessoas e acontecimentos passados e corremos o risco de perdêlas. "Não penso que, com o livro, eu vá resolver aquilo que não estava resolvido, que vou superar essa ambivalência" (Fuks, 2016, par. 9). A ambivalência diz respeito à relação estabelecida com o país de onde os pais foram expulsos e, também, ao próprio passado. Diante da posição assumida pelo autor, podemos perguntar: para que serve isto que se escreveu? $\mathrm{O}$ autor não permanece nas linhas do escrito, não há uma vida vivível nas linhas de um livro, há uma deriva em relação ao que se viveu, considerado inacabado. Paradoxalmente, consideramos que escrever e perder são verbos simultaneamente conjugáveis, dependendo de exercícios de leitura que preservem e transcendam o que foi lido. Na própria composição de sua escrita, Fuks depara-se com o fracasso que é constitutivo da atividade de escrever.

Isto não é uma história. Isto é história.

Isto é história e, no entanto, quase tudo o que tenho ao meu dispor é a memória, noções fugazes de dias tão remotos, impressões anteriores à consciência e à linguagem, resquícios indigentes que eu insisto em malversar em palavras. Não se trata aqui de uma preocupação abstrata, embora de abstrações eu tanto me valha: procurei meu irmão no pouco que escrevi até o momento e não o encontrei em parte alguma. Alguma ideia talvez lhe seja justa, alguma descrição porventura o evoque, dissipei em parágrafos sinuosos uns poucos dados ditos verídicos, mais nada. Não se depreenda desta observação desnecessária, ao menos por enquanto, a minha ingenuidade: sei bem que nenhum livro jamais poderá contemplar ser humano nenhum, jamais constituirá em papel e tinta sua existência feita de sangue e de carne. (Fuks, 2015, p. 23)

Incidindo sobre o próprio material escrito, o autor estabelece limites ao exercício da escrita. O narrador forja-se como elemento intersticial entre a busca e a perda daqueles seres que ama, daqueles com quem se estabelece uma relação viva e que não se restringe ao que está escrito. O ingrato exercício da escrita não resolveu a ambiguidade do indivíduo Julián Fuks, mas o livro aproxima-se dos esforços de elaboração política do passado. Considerando que o passado não seja "algo em si mesmo", as atividades reminiscentes só se tornam efetivas com o enfrentamento da vertigem produzida pela perspectiva que se lança sobre o tempo. Escrever é um risco, mas salvaguarda a liberdade de desdobrar algumas imagens do tempo que não haviam sido reconhecidas. A resistência fertiliza a possibilidade de produção de memória sobre o passado, mas, como escrita literária, pode ser remetida a exercícios políticos imprevisíveis, como os que se tornam essenciais diante da violenta máquina de esquecimento forjada sobre o nosso passado recente. Recordar pode ser um antídoto à suposta norma de reiteração da barbárie no decorrer da história. A respeito da memória assumidamente equivocada do narrador no romance 


\section{pro.posıções}

$e$-ISSN 1980-6248

http://dx.doi.org/10.1590/1980-6248-2019-0093

A resistência, também se torna possível nos posicionarmos como aqueles que precisam reivindicar que o passado aconteceu e que ainda não fomos restituídos do que perdemos com a ditadura civil-militar.

O texto literário pode se tornar um fragmento da partilha que se torna possível agora. Mesmo que, para o autor, o livro não sirva como expurgo ou definição final do que se é. Ler o texto literário pode nos ajudar a desdobrar um conjunto de imagens interrompidas do passado. Os escritores citados - Bolaño e Fuks - não nos oferecem perspectivas de redenção por intermédio de prescrições morais. Os narradores forjados não ocultam sua fragilidade, constituindo lugares enunciativos em que o "eu" se torna secundário em relação à própria recordação, sendo sacudido por temas e problemas que dizem respeito a todos nós, latinoamericanos. Mesmo que não se dirijam à articulação de uma redenção, os livros de Bolaño e Fuks - interpretados por nós como parte de esforços estéticos e políticos de contraposição ao silenciamento compulsório das dissidências, como aquelas vividas em infâncias subalternizadas e desqualificadas - contrastam as imagens da solidão dos narradores, voltados à força da recordação que transtorna, às experiências coletivas vividas por marginalizados e desajustados às normas vigentes.

No romance de Bolaño (2009), são os passeios e os sonhos de jovens poetas esmagados pela violência de Estado - pela Cidade do México entre os anos de 1960 e 1970 que serão evocados como o que se tornou inesquecível, justamente o que passou pelo crivo - amplo, delirante, enlutado e sobrevivente - da recordação. A narradora Lacouture evoca o canto dos poetas desaparecidos na América Latina, indicando que ele pode nos servir como amuleto. Os jovens que jogaram com suas próprias vidas para não se rebaixarem ao terror instituído em diferentes países da América Latina cantam, após a constatação de que foram sacrificados. A narradora interpreta o canto: "falava do destemor e dos espelhos, do desejo e do prazer" (Bolaño, 2009, p. 131). Uma história de terror que termina com o reconhecimento de que a felicidade foi interrompida.

Também em Fuks (2015) a solidão do narrador e a solidão da escrita não se cristalizam como vivências sufocantes. No texto, o narrador desgarra-se de sua própria individualidade e junta-se a mulheres militantes na Argentina que reivindicam seus netos arrancados da família, desaparecidos. Há êxtase e euforia, algo no país parece ter sido colocado no seu devido lugar, algo foi restituído aos perseguidos. 


\section{pro.posıções}

$e$-ISSN 1980-6248

http://dx.doi.org/10.1590/1980-6248-2019-0093

Há algo de êxtase no que ali se vive, há uma euforia que perpassa os ombros, que se intui de mente a mente, há um furor coletivo que ninguém poderia prever. No rádio o locutor se empenha em definir o acontecimento, este capítulo eloquente da história nacional, este triunfo tardio contra o terror e o esquecimento, este desfecho feliz contra toda expectativa, este sentimento de reconciliação do país. (Fuks, 2015, p. 130)

Conectando a história do irmão adotivo - de que mãe e de que pai ele foi desgarrado? - com a história de desaparecidos políticos na Argentina, o narrador assume certa destinação aos seus afetos e incongruências em torno da composição de uma imagem da família. O narrador experiencia a euforia da multidão que reivindica seus entes queridos e perdidos. Talvez se possa andar por Buenos Aires de um modo mais tranquilo, finalmente será possível forjar um lar no país que expulsou os seus pais. Mas o romance fala de derrotas, aquilo que se escreve é a pequena vitória do que foi esquecido. O lugar do narrador, no entanto, não garante nenhuma sensação vitoriosa final. "Entendendo enfim, situado enfim, decido enfim partir: nada me restituirá lugar algum, nada reparará o que vivi, pois não parece haver nada a ser reparado em mim" (Fuks, 2015, p. 131). O fracasso exemplar da escrita? A literatura desvia-se da resolução definitiva, e o narrador pode, enfim, partir. A viagem não é apenas a denotação do deslocamento espacial que se pode realizar, mas a alegoria do exílio de onde se pode indicar o quanto já nos encontramos enredados em dispositivos, sendo o mais primário a própria linguagem.

A promessa da escrita literária não se volta, exclusivamente, para quem escreveu o romance. Só pode ser cumprida na extensão do tempo que separa o texto daqueles que serão capazes de acolhê-lo. Por isso, defendemos que as narrativas subalternizadas de infâncias e de memórias dissidentes precisam encontrar leitores que se desviem da suposta necessidade de suas próprias épocas. Para nós, é de suma importância que possamos considerar o quanto de nós mesmos se revela quando nos sentimos interceptados por histórias marcadas pelo funcionamento de regimes excludentes, que acabam por impor a tarefa de que não esqueçamos o passado, para que, finalmente, possamos estar presentes. Só pode haver restituição se houver quem recolha as histórias ainda consideradas malditas. 


\section{pro.posıções \\ $e$-ISSN 1980-6248 \\ http://dx.doi.org/10.1590/1980-6248-2019-0093 \\ Infâncias e vidas nuas: entre o totalitarismo e as violências de gênero}

A infância, como um conceito secular da cultura ocidental moderna, produzido por imagens, códigos e práticas sociais e históricas, tem sua força simbólica na ideia de inocência, noção que funda uma natureza infantil, dando vida a uma "criança ideal-típica" (Palmary \& Mahati, 2015, citados por Burman, 2015). O efeito produzido por essa criança ficcional é tornarse a imagem especular de todas as infâncias, um ideal normativo que não apenas se aplica às crianças, mas também aos adultos que com elas se relacionam. Inocência e origem acoplam-se de tal forma a constituir a marca do começo da história, do desenvolvimento da vida, cuja narrativa é tecida por uma política reprodutiva, a qual, além de ser disparada por essa origem, é criadora de um telos (Haraway, 2016).

Entre a origem e o telos, o trajeto a ser percorrido é o do desenvolvimento movido pelo progresso, e a vida que o protagoniza tem no "eu" autossuficiente e possuidor de uma identidade coerente o seu emblema. Criado por uma ontologia que se consolida como um regime de inteligibilidade da vida, esse "eu" apresenta-se como a "verdade de si", que abarca um conjunto de normas e um sistema de racionalidade produzidos historicamente, e representa a ideia moral da racionalidade liberal (Butler, 2016a). Como políticas de verdade sobre a vida, esse regime de inteligibilidade arbitra sobre campos de reconhecimento de existências, que demarcam os territórios da normalidade e da abjeção. Normas de gênero, raça, classe social, saúde, felicidade, produtividade, comportamentos, idades produzem vidas que se consagram como modos de existir legitimados. Ocupar territórios que não estão sob a chancela dessas normas implica perder as prerrogativas ontológicas de sujeito e encarnar vidas consideradas como não válidas e ininteligíveis.

É isto que faz a tarefa autobiográfica tão difícil. Apresenta-se como fácil, óbvia até; mas reconhecemos bem como nessa facilidade, se escondem as premissas das formas que combatemos - se escondem a construção do indivíduo como o conhecemos hoje em dia, a constituição de histórias identitárias e do apagamento daquilo que não se lhes conforma, a reiteração formulaica dos lugares que se dão à compreensão, que nos precedem, que partilhamos, também que nos dominam. (Feijo, 2017, pp. 195-196)

$\mathrm{Na}$ tessitura da memória, o avesso da identidade do progresso, encarnada no "eu" da autossuficiência e assumido como ponto de origem e fim da narrativa autobiográfica, é o 


\section{pro.posıções}

$e$-ISSN 1980-6248

http://dx.doi.org/10.1590/1980-6248-2019-0093

inenarrável, o que não pode ser contado porque é escombro da história e está condenado ao desaparecimento. Na denúncia da produção de uma verdade de si, como prerrogativas identitárias, Pedro Feijo resiste a essa narrativa do apagamento e põe a ver os efeitos das políticas de verdade, tanto na forma de seus constrangimentos mediante suas convocatórias de conformação quanto nos modos inventivos de combate a essas exigências, em que a memória dos escombros aparece com vigor.

Essas políticas de verdade incidem sobre o gênero ao validar uma identidade linear, que é a expressão coesa e coerente das noções e dos ideais produzidos para dar inteligibilidade e legitimidade aos corpos masculinos e femininos em sua estrutura binária. São discursos que sustentam a narrativa fictícia do gênero substantivo, arrancado da vida social, dado o seu caráter de essência, e alinhado com perfeição à verdade de si e da vida (Butler, 2016a). Entretanto, como efeito da subjetivação de uma norma, esse gênero substantivo é performativo ao produzir o que ele nomeia, na medida em que é criado pelos modos como sujeitos, corpos, linguagens e objetos expressam os gêneros. Sem sobrevivência duradoura e estável, as normas têm suas rachaduras e ruídos, de forma que, mesmo com o esforço de manter a sua unicidade e coesão, as fugas e os escapes têm acontecimento inevitável nesse jogo performativo, dando lugar também ao que é abjeto (Butler, 2015, 2016a).

Reconheci as partes que me amedrontavam, mas também a sua potência: é o monstro que se revolta, que me permite ter a força para me maquilhar, para ser bicha, para usar saias, foi o monstro que, nos meus sonhos, veio em meu socorro e mandou ao caralho aqueles que me gozavam por andar de mãos dadas com um gajo. Ele dá-me a raiva e a fúria que eu tranquei de lado, ele quer pancada quando eu quero fugir, ele grita sou paneleiro sim caralho, qual é o teu problema seu procriador de merda quando eu só me quero esconder. (Feijo, 2017, p. 200)

O monstruoso aparece para mostrar a sua potência disruptiva, embaralhando os fios da narrativa do desenvolvimento e do progresso, regidos pelos estatutos de sujeito e de vida que definem como ela "deve" se desenrolar. Feijo traz nas revoltas, nas fúrias, nas maquiagens, nas saias, nos sonhos, nas fugas, nos gritos da infância a força do que não se pode esconder em nome de uma razão de viver; é a força do próprio abjeto e, junto com ele, o repúdio contra o que a norma se esforça em proteger: a vida validada como a única vida possível (Butler, 2016b).

Em que pesem as diferenças entre as narrativas literárias sobre as memórias do terror de Estado de Bolaño e Fuks e as de Feijo sobre as memórias da infância abjeta, as confluências estão nas escrituras que, na contramão da pretensa tarefa de recuperar as lembranças do passado 


\section{pro.posıções}

$e$-ISSN 1980-6248

http://dx.doi.org/10.1590/1980-6248-2019-0093

e de reintegrar os elos de um "eu" perdido nesse tempo, se engajam nas escutas dos apelos desse tempo pretérito para o libertar do esquecimento, no mesmo instante em que é provocado pelas inquietações do presente. São escrituras em que o presente é o tempo do assombro do passado (Butler, 2016b).

A vida é ponto de apoio de resistências, lembra-nos Pelbart (2011), e o direito de aparecer no espaço público é uma dessas resistências. Entretanto, esse direito é constrangido por normas que funcionam como estatutos de quem pode ou não ser reconhecido como pessoa ou cidadão/cidadã. Essas normas definem e decidem sobre questões como: "Quais humanos contam como humanos? Quais humanos são dignos de reconhecimento na esfera do aparecimento, e quais não são?” (Butler, 2018, p. 43).

Nesse campo das normas de reconhecimento social, Agamben (2002) discute as relações entre a vida e o poder soberano. Ele vê na identidade entre vida e política o fundamento do totalitarismo ao serem criadas prerrogativas jurídicas e políticas, no âmbito do Estado, para destruir vidas sem cometer delitos; para matar pessoas, que são privadas de seus direitos, sem cometer homicídios; para violar, abusar e torturar corpos sem praticar violências. "Vida nua" é o que Agamben (2002) nomeia como a expressão da biopolítica, dada a estreita implicação entre zoé, a vida comum a todos os seres viventes, o substrato biológico da existência, e bios, que é a vida na polis, na esfera da cidadania, a vida política. Entretanto, o fato de a vida nua ser passível de violação e destruição sem que haja um crime faz dela o próprio limiar da biopolítica.

O poder soberano é a esfera que arbitra sobre o poder de viver e de matar, decretando, para isso, a suspensão do direito para fazer existir a vida nua, a vida sacra. Afastada do seu significado religioso, a sacralidade, para Agamben (2002), sob a égide do poder soberano, passa a estar estreitamente vinculada à ordem jurídico-política, de modo que vida sacra é aquela que só existe quando é acionada a suspensão do direito, o Estado de exceção que decreta a sua morte sem que se tenha cometido um crime ou sem que um sacrifício tenha sido vivido com a sua destruição. É, portanto, a própria vida matável e insacrificável; uma vida que excede tanto o direito humano quanto o direito divino.

Para Agamben (2002), a biopolítica é o modus operandi da vida moderna, é a forma como os Estados-nação se sustentam na demarcação constante entre a "vida autêntica", aquela que tem relevância para a organicidade do próprio Estado, e a "vida nua", aquela que perde valor político-jurídico e se torna indigna de ser vivida. Nessa estrutura biopolítica, o poder 


\section{pro.posıções}

$e$-ISSN 1980-6248

http://dx.doi.org/10.1590/1980-6248-2019-0093

soberano opera a decisão sobre o valor e o desvalor da vida, a autorização da aniquilação de vidas que ameaçam o organismo do Estado.

"Matar a fim de viver", afirma Achille Mbembe (2018, p. 20), ao se reportar à racionalidade da vida, no exercício da soberania do Estado moderno, que imprime legitimidade ao extermínio do Outro, considerado como ameaça e perigo à vida em sua forma inteligível. Opera-se a necropolítica, que põe em execução o terror para marcar a abjeção no corpo político como forma de extirpá-la em nome da razão e da verdade.

É possível argumentar que o poder soberano do Estado-nação, que decreta a vida nua e executa a necropolítica, opera também como um regime de inteligibilidade ao decidir sobre as vidas válidas ou não, delimitando campos de reconhecimento e aparecimento social. Nessa topografia, o direito de aparecer socialmente é regulado por esse regime ao distinguirem-se as pessoas elegíveis e não elegíveis para o seu exercício: quem pode aparecer na vida social sem ser alvo de injúrias, violências e mortes? $\mathrm{Na}$ esfera do aparecimento, não há, portanto, universalidade, já que se torna imprescindível interrogar as formas diferenciais de poder corporificadas em condições políticas que são indutoras de precariedades e do apagamento social (Butler, 2018).

$\mathrm{Na}$ contracorrente do apagamento social, está o esburacamento da história, na busca pelo avesso de sua narrativa totalizadora (Pelbart, 2011). O apelo político para a escuta ressonante das vozes silenciadas e das ruínas deixadas para trás pelas barbáries é um modo de responder às inquietações do presente, ainda marcado pelas ameaças do terror; é um modo de aparecer socialmente. Nessa escavação, os rastros apagados pela narrativa épica são postos à mostra por uma história que é escovada "a contrapelo" (Benjamin, 1985, p. 225). Na narrativa totalizadora, a memória dos mortos sem luto, das histórias inenarráveis, é sufocada. A resistência ao esquecimento é a transmissibilidade do inenarrável, das vidas nuas, como forma de se opor à repetição das violações e das opressões. O esquecimento aqui, como ressalta Jeanne Marie Gagnebin (2009), não pode ser entendido simplesmente como uma lacuna ou espaço em branco da memória, mas como uma atividade produtora do apagamento e da renúncia. Lutar contra o esquecimento é tarefa do historiador, que se faz política, ética e psíquica por ser uma luta contra a repetição do horror e pela sobrevivência das memórias dos mortos para uma relação crítica e diferente com o presente (Gagnebin, 2009). 


\section{pro.posıções}

$e$-ISSN 1980-6248

É o esburacamento da própria história que Nicolás Arena se propõe a fazer em sua narrativa ao escrever uma "carta aberta" àquele que o abusa e violenta na infância.

Lo tuyo no fue un acto incestuoso que despertó mi libido, no fue un juego en el que ambos ganamos algo, en el que ambos nos hayamos divertido, en el que compartimos alguna derrota; lo tuyo no fue nuestro, fue un acto de sometimiento que despertó mi más temprana miseria, enseñándome a reprimirme, mutilándome, de abi en adelante, toda la vida, para dejar solo lo que estaba "bien" y, aunque suena terrible, sentó las bases de una estrategia para sobrevivir en un mundo que sentía que me quería pisar al igual que vos. ...

Alli me quedo yo, al margen, con mis referentes de lucha y justicia social que visibilizan nuestros crímenes para que la justicia sea que no los volvamos a cometer, me quedo con los que usan toda esa ira como combustible de actos creativos pasionales. Me quedo con aquellos que comprenden el valor de cada vida y la urgencia de cada herida. Me quedo con los maricones, las tortas, las travas, los trans, con los negros, las putas, los locos, las discas, los pobres y todo lo que el poder desprecia....

Sin embargo acá estoy, aceptando que no olvido, que no perdono. Dándome cuenta de que los silencios nos aprisionan, reconociendo que evadirme sólo contribuyó a que se siga agrandando el hueco en mi estómago ${ }^{3}$. (Arena, 2017, pp. 254-255)

A memória como luto do trágico, da vida nua sobre a qual ele se sustenta e se perpetua, faz aparecer a crítica de sua naturalização ao escavar no passado as injúrias e as violências como resposta a um presente que se inquieta e se interroga com a dor. Tão mutiladora quanto a produção da vida nua é a impossibilidade de dizê-la, a estratégia de arrancar-lhe a palavra e a condenação de sua memória. A denúncia e a crítica dessas mutilações são a própria escritura de Arena como resistência à produção do imemorável, como forma de fazer aparecer o que deveria ser esquecido. Sua escritura retira do esquecimento a possibilidade de que a sua história de violação não se repita e ganhe naturalidade, de que ela poderia ter sido diferente. Trata-se de trazer à tona as esperanças sufocadas do passado para inscrever, no presente, os apelos por um futuro diferente do que "sempre foi" (Gagnebin, 2018). O lamento da dor converte-se em

\footnotetext{
${ }^{3} \mathrm{O}$ teu não foi um ato incestuoso que despertou minha libido, não foi um jogo no qual nós dois ganhamos, no qual nós dois tenhamos nos divertido, no qual compartimos alguma derrota; o teu não foi nosso, foi um ato de submissão que despertou em mim a mais tenra miséria, ensinando-me a reprimir-me, mutilando-me, daí em diante, por toda a vida, para deixar apenas o que estava "bem" e, ainda que soe terrível, assentou as bases de uma estratégia para sobreviver em um mundo que sentia que queria me pisar, assim como você. ...

Ali fico eu, à margem, com minhas referências de luta e justiça social que visibilizam nossos crimes para que a justiça seja que não voltemos a cometê-los, fico com os que usam toda essa ira como combustível de atos criativos passionais. Fico com aqueles que compreendem o valor de cada vida e a urgência de cada ferida. Fico com os maricas, as lésbicas, as travestis, os trans, com os negros, as putas, os loucos, os inválidos, os pobres e tudo que o poder deprecia. ...

Entretanto aqui estou, aceitando que não esqueço, que não perdoo. Dando-me conta de que os silêncios nos aprisionam, reconhecendo que me evadir apenas contribuiu para que siga aumentando o buraco em meu estômago. (tradução nossa)
} 
reivindicação contra a inevitabilidade da barbárie ao trazer as vozes que ecoam as esperanças que não puderam se cumprir e saem das bocas daqueles/as que sabem o valor da vida e a urgência da ferida (Arena, 2017).

\section{Luto público e aparecimento social como políticas de resistência contra a barbárie}

O luto público e o aparecimento social, em suas possibilidades e constrições, na perspectiva de Butler (2018), remetem às formas de distribuição da condição precária, que implicam uma administração biopolítica dedicada à demarcação valorativa das vidas em termos de dignidade, direitos, proteção e pertencimento político. Essa valoração, como já discutimos, ancora-se em regimes de inteligibilidade que são definidores dos estatutos de sujeito e de vida.

Para Butler (2018), todos nós somos dependentes de um mundo social, econômico e político, que extrapola a condição de um "eu” individual e, mais do que isto, lhe dá acabamento. Nossa condição precária constitutiva é a necessária abertura ao outro, à alteridade que desmonta a ideia da autossuficiência. Entretanto, existem pessoas e populações a quem as condições de vulnerabilidade e de exposição à violência do Estado são induzidas e maximizadas por decisões e ações políticas, que efetivam a distribuição desigual dessa condição precária, o que se configura como precariedade.

A distribuição desigual da condição precária acarreta, também, a distribuição desigual do luto público, que, por sua vez, está implicado na regulação da comoção social, nos modos como uma sociedade elabora as respostas afetivas às suas tragédias, significa o trágico e decreta as censuras contra os afetos e as memórias da dor. A regulação dos afetos sociais tem seu fundamento nos campos de reconhecimento social, arregimentados nos estatutos de sujeito, que julgam as vidas dignas de luto, para as quais os esforços de salvamento e libertação são válidos, e as que devem estar destinadas ao extermínio, para as quais tanto os prantos pela perda e as lutas pela memória são rechaçados. Problematizar as normativas que sustentam esses julgamentos e validações, diz Butler (2016b), é uma forma de luta política contra a barbárie. Nessa luta, está também a produção de memória como a elaboração de uma comoção que ressignifica a submissão forçada, tal como fazem as narrativas literárias de Bolaño e Fuks e as 


\section{pro.posıções}

$e$-ISSN 1980-6248

http://dx.doi.org/10.1590/1980-6248-2019-0093

memórias de infâncias dissidentes e violentadas de Feijo e Arena, ao converterem corpos precários, vestígios da violação, em respostas ativas ao sofrimento (Butler, 2016b).

O luto público exclui a vida nua no instante em que no seu lugar fica o rito de celebração da morte, legitimado pelo estatuto de reconhecimento do humano que confere a essa vida rechaço e abjeção. O desnudamento da vida tem na ameaça à inteligibilidade e ao progresso da civilização o seu fundamento, para o qual a violência, a tortura e a morte já não são mais sofrimentos, já não justificam o luto, mas consistem em estratégias de preservação da ordem social e de proteção da vida que sustenta essa ordem.

A persistência do aparecimento social, quando e onde os apagamentos são produzidos e como forma de expor o desnudamento da vida em sua precariedade e abandono, é crítica e resistência às normas que fundam o paradigma da vida humana e, com ele, as vidas que têm ou não valor. Os sentidos do aparecimento, tecidos por formas diferenciais de poder, mediam as liberdades de aparecer na vida social. Compreender, interrogar e intervir nessas mediações, como ressalta Butler (2018), é central para a luta democrática, de modo a pôr em questão as formas desiguais de aparecimento e resistir contra elas.

Nosso argumento vai na direção da produção de memórias como possibilidade de aparecimento social nos campos minados pela narrativa épica, nas arenas onde a história que se oficializa é a que deposita nos escombros as dores e os prantos dos mortos de que necessita para estar viva. "Deve-se regenerar os meios envenenados", diz Isabelle Stengers (2017, p. 8), como forma de reativar o que foi confiscado pelos colonizadores, protagonistas da narrativa épica. Resistir é regenerar o que foi envenenado a partir da ruína, do traumático, do encerramento de Lacouture no banheiro da Universidade, da mariconice aviltada de Feijo e da violação sofrida por Arena. É reativar o passado, nunca para conservá-lo ou recuperar uma tradição autêntica, mas para libertá-lo do envenenamento da verdade do progresso, da eficiência e da produtividade. É ler a poeira dos livros, tal como o faz Lacouture, e o que ela pode guardar de mistério na ousadia de reabitar o mundo envenenado. É ouvir os cantos de uma geração de jovens latino-americanos sacrificados pelo terror que sobrevivem para narrar essa história, dissipar a poesia e fazer ressoar o amor entre eles, o desejo e o prazer entoados como um amuleto (Bolaño, 2009). 


\section{pro.posıções \\ $e$-ISSN 1980-6248 \\ Considerações finais: a memória como luta contra o esquecimento}

http://dx.doi.org/10.1590/1980-6248-2019-0093

Quebrar os silêncios, recuperar a palavra, fazer a memória sobreviver, exibir os corpos com suas linguagens e movimentos, viver o luto, para além do pranto, como luta contra o esquecimento e o apagamento das dores, das injustiças sociais e das vidas nuas, tudo isso se alia com a denúncia e a resistência ao que o poder se esforça, de modo insistente, para destruir e transformar em estilhaços. Esse esforço é movido pela proteção e manutenção de uma vida cuja soberania se sustenta no extermínio de outras vidas, corpos e histórias.

$\mathrm{Na}$ linha transversal que buscamos desenhar entre os temas discutidos, a possibilidade de desdobramento do passado interroga as separações artificiais entre as épocas históricas. A partir de exercícios estético-políticos sobre o passado, as atividades reminiscentes em protagonismo, neste artigo, reivindicam uma forma de aparecimento que não se compraz com os estereótipos. Para nós, a memória tem sentido político, e partilhar vestígios do que foi vivenciado sob regimes de condução da vida social, que se estruturam por intermédio da produção de inteligibilidades e abjeções, garante a complexificação de nossa compreensão do tempo histórico. A escritura de textos literários que desmancham a obviedade do passado alcança o presente, em que localizamos a urgência do trabalho crítico, por intermédio do qual vislumbramos esforços pessoais e coletivos de constituição de vidas legítimas.

Ao nos sentirmos interceptados pelas escrituras que mostram fragmentos de vidas legítimas, procuramos defender a convergência entre aquilo que foi escrito e nós, que recolhemos o gesto que nos foi lançado. O silenciamento do sofrimento de experiências sexuais e de gênero dissidentes, de infâncias paradoxalmente assentadas na violência e na resistência em relação ao caráter monolítico do passado, pode ser rompido. Práticas de interpretação mobilizam sentidos em que uma imagem do passado ainda persiste. Sem reconhecer a imagem, não conseguiremos estabelecer atitudes críticas que assegurem novas formas de responsabilidade e debate público. A infância, como expressão daquilo que precocemente é submetido a processos de contenção sexopolítica, dialoga com fragmentos inconclusos do passado, interpelando o presente. A precocidade do controle sexopolítico não oculta as ferramentas utilizadas para marcar corpos e vidas catalogadas como vivíveis ou não. Escrever e falar sobre o sofrimento imposto às crianças a partir da produção de lugares enunciativos renovados interrompe o continuísmo abstrato do desenvolvimentismo na vida. Assim também 


\section{pro.posıções}

$e$-ISSN 1980-6248

se dá em torno do reconhecimento de escritas literárias que multiplicam as referencialidades sobre o passado de opressão e perseguição políticas na América Latina, incomodamente atuais. Abrir o passado para um escrutínio político parece-nos uma atitude possível diante da violência ainda atual em relação às dissidências.

\section{Referências}

Agamben, G. (2002). Homo sacer: o poder soberano e a vida nua. Belo Horizonte: Editora UFMG.

Arena, N. A. B. (2017). Carta abierta. In J. M. Burgos \& E. Theumer (Orgs.), Mariconcitos: feminidades de niños, placeres de infancia (pp. 245-256). Córdoba: Edición de los autores.

Benjamin, W. (1985). Obras escolbidas 1: magia e técnica, arte e política: ensaios sobre literatura e história da cultura (2a ed.). São Paulo: Brasiliense.

Benjamin, W. (2011). Origem do drama trágico alemão. Belo Horizonte: Autêntica Editora.

Bolaño, R. (2009). Amuleto. São Paulo: Companhia das Letras.

Burgos, J. M., \& Theumer, E. (Orgs.). Mariconcitos: feminidades de niños, placeres de infancia. Córdoba: Edición de los autores.

Burman, E. (2015). Limits of deconstruction, deconstructing limits. Feminism \& Psychology, 25(3), 408-422. doi:10.1177/0959353515582274

Butler, J. (2015). Cuerpos que importan: sobre los límites materiales y discursivos del "sexo" (2a ed.). Buenos Aires: Paidós.

Butler, J. (2016a). Problemas de gênero: feminismo e subversão da identidade (10a ed.). Rio de Janeiro: Civilização Brasileira.

Butler, J. (2016b). Quadros de guerra: quando a vida é passivel de luto? (2a ed.). Rio de Janeiro: Civilização Brasileira.

Butler, J. (2018). Corpos em aliança e a política das ruas: notas para uma teoria performativa de assembleia. Rio de Janeiro: Civilização Brasileira. 
Feijo, P. (2017). O nome dela é Pedro e ela é um monstro. In J. M. Burgos \& E. Theumer (Orgs.), Mariconcitos: feminidades de niños, placeres de infancia (pp. 193-201). Córdoba: Edición de los autores.

Fuks, J. (2015). A resistência. São Paulo: Companhia das Letras.

Fuks, J. (2016, 25 de novembro). “O Brasil é incapaz de refletir sobre o seu passado”, diz Julián Fuks. Entrevista por Paula Pires. Revista Cult. Recuperado de https:/ / revistacult.uol.com.br/home/o-brasil-e-incapaz-de-refletir-sobre-seu-passadodiz-julian-fuks/

Gagnebin, J. M. (2009). Lembrar escrever esquecer (2a ed.). São Paulo: Editora 34.

Gagnebin, J. M. (2018). Walter Benjamin: os cacos da história. São Paulo: n-1 edições.

Haraway, D. (2016). Manifesto ciborgue: ciência, tecnologia e feminismo-socialista. In T. Tadeu (Org.), Antropologia do ciborgue: as vertigens do pós-humano (2a ed., pp. 33-118). Belo Horizonte: Autêntica.

Mbembe, A. (2018). Necropolítica: biopoder, soberania, estado de exceção, política da morte. São Paulo: n-1 edições.

Pelbart, P. P. (2011). Vida capital: ensaios de biopolítica. São Paulo: Iluminuras.

Piglia, R. (2017). O último leitor. São Paulo: Companhia das Letras.

Stengers, I. (2017). Reativar o animismo. Caderno de Leituras, (62), 1-15. Recuperado de https://chaodafeira.com/wp-content/uploads/2017/05/caderno-62-reativar-ok.pdf

Submetido à avaliação em 06 de agosto de 2019; aceito para publicação em 26 de novembro de 2019. 